\title{
Uğur Gürsu, Kazak Atasözleri, Türk Dil Kurumu Yayınları, Ankara 2017, 1175 s. ISBN: 978-975-16-3330-9 (Tanitima)
}

Ömer Güven ${ }^{1}$

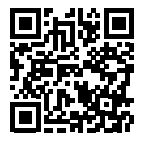

'Ar. Gör., Amasya Üniversitesi, Fen-Edebiyat Fakültesi, Türk Dili ve Edebiyatı Bölümü, Amasya, Türkiye

Sorumlu yazar/Corresponding author: Ömer Güven,

Amasya Üniversitesi, Fen-Edebiyat Fakültesi, Türk

Dili ve Edebiyatı Bölümü, Amasya, Türkiye

E-mail: omer.guven@live.com

Geliș tarihi / Date of receipt: 15.11 .2017

Kabul tarihi/Date of acceptance: 15.11.2017

Atıf/Citation

Güven, Ömer. "Kitap tanıtımı: Kazak Atasözleri,

Uğur Gürsu." Türk Dilive Edebiyatı Dergisi, Cilt: 57 ,

Sayl: 57, 2017, s. 275-277

10.26561/iutded.370921

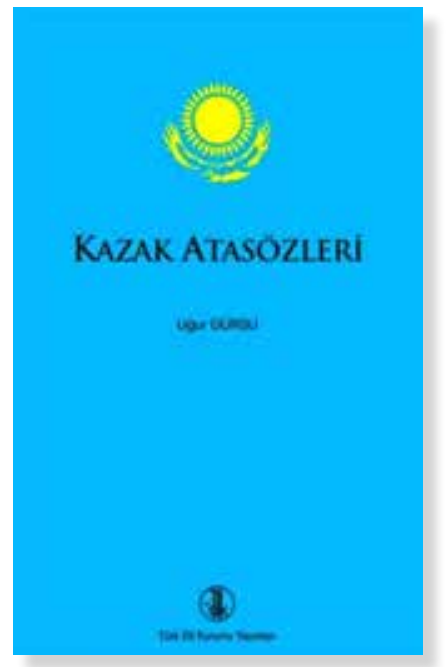


Atasözü, atalarımızın uzun denemelerine dayanan yargıların genel kural, bilgece düşünce ya da öğüt olarak düstûrlaştıran ve kalıplaşmış biçimleri bulunan milletçe benimsenmiş özlü sözlerdir. ${ }^{1}$ Atasözleri gelişip yaygınlık kazandığı toplumların adeta aynasıdır. Atasözleri sayesinde toplumların pek çok kültürel ve sosyal ögeleri ile yaşam tarzları, gelenekleri, görenekleri, inançları gün yüzüne çıkabilmektedir. Ayrıca derin gözlem ve tecrübeler sonucunda oluşan atasözleri insanlara yol gösterici niteliktedir. Sözlü kültür unsurları olan atasözleri aynı zamanda dil ve edebiyat bakımından da zengin veriler içermektedir. Çoğu zaman da mecaz anlam taşıyan atasözleri ile anlatılmak istenen düşünce ve yargılar etkili bir şekilde ifade edilmiş olur.

Kazak atasözleri ile ilgili Doç. Dr. Uğur GÜRSU tarafından 2017 yılında kapsamlı bir çalışma yapılmıştır. Kazak Atasözleri adını taşıyan eser, "Kısaltmalar", "Çeviri Yazı Sistemi", "Ön Söz" ve "Giriş" ile başlamaktadır. Ön Sözde ilk olarak atasözlerinin özellikleri üzerinde kısaca durulmuş ardından da bu çalışmanın hedefi açıklanmıştır. Yazar bu çalışmayı gerçekleştirmedeki hedefini; "Türkiye Türkçesindeki ve Kazak Türkçesindeki atasözlerini karşılaştırmalı biçimde ele alarak iki lehçenin atasözü zenginliğini ortaya koymak ve bunu yaparken de Kazak Türkçesindeki ve Türkiye Türkçesindeki atasözleri arasındaki ortaklıkları, benzerlikleri ve farklılıkları tespite çalışmaktır ${ }^{2 "}$ şeklinde ifade etmektedir. Ön Söz bölümünde son olarak kısaca eserin bölümleri tanıtılmış ve eserin hazırlanışı üzerinde durulmuştur.

Giriş (s. 14-22) bölümünde ise ilk olarakatasözü kavramı ele alınmıştır. Ibrahim Şinasi'den başlayarak bu alanda önemli çalışmalar yapmış olan araştırmacıların atasözü tanımları ile çeşitli sözlüklerden alınan tanımlar üzerinde durulmuştur. Türkiye Türkçesindeki atasözleri tanımlamalarından sonra Kazak Türkçesinde atasözü terimi açıklanmıştır. Bunu yazar; "Kazak Türkçesinde atasözlerini ifade etmek için "maqal ve mätel" terimi kullanılmıştır ki, bu terim "maqal ve mätel" adlı iki ayrı sözcükten oluşmaktadır" şeklinde bir değerlendirme yaptıktan sonra "maqal ve mätel" kavramları tanımlamış ve bu kavramların arasındaki farkları örnekler de vererek açıklamıştır.

Çalışmanın Birinci Bölümü (s. 23-287) Türkiye Türkçesindeki ve Kazak Türkçesindeki Atasözlerinin Konularına Göre Karşılaştırılması adını taşımaktadır. Bu bölüm de kendi içinde on dört konu başlığından oluşmaktadır. Bunlar; Vatan, Millet, Halk ve Yönetim ile IIIgili Atasözlerinin Karşılaştırılması, Din ve Inanışlar ile Ilıili Atasözlerinin Karşılaştırılması, Insan Iliş̧kileri ile Ilgili Atasözlerinin Karşılaştırılması, Kişilik Özellikleri ile Illgili Atasözlerinin Karşılaştırılması, Toplumsal Statü ile IIlgili Atasözlerinin Karşılaştırılması, Eğitim, Bilim ve Sanat ile IIlgili Atasözlerinin Karşılaştırılması, İ̧̧, Çalışma ve Meslekler ile IIlgili Atasözlerinin Karşılaştırılması, Hayat, Ölüm ve Sağlık ile IIlgili Atasözlerinin Karşılaştırılması, Insan Vücudu ile İlgili Atasözlerinin Karşılaştırılması, Özel Günler ve Merasimler ile Illgili Atasözlerinin Karşılaştırılması, Giysilerve Eşyalarile IlgiliAtasözlerinin Karşılaştırılması, Yiyecekvel Içeceklerile IIIgili Atasözlerinin Karşılaştırılması, Hayvanlar ve Avcılık ile Illgili Atasözlerinin Karşılaştırılmasıı, Tabiat ile Ilgili Atasözlerinin Karşılaştırılması şeklindendir. Burada her bir başlık altında

1 Ömer A. Aksoy, Atasözleri ve Deyimler Sözlüğü, İnkılâp Yayınevi, Ankara.,1971, s. 36.

2 Uğur Gürsu, Kazak Atasözleri, TDK Yay., Ankara, 2017, s. 17.

3 Gürsu, a.g.e., s. 20. 
Türkiye Türkçesindeki ve Kazak Türkçesindeki atasözleri konuları bakımından tasnif edilmiş ve örneklerle desteklenmiştir. Örnekler hem Kazak Türkçesi ile hem de Türkiye Türkçesi ile birlikte verilmiştir. Konuları bakımından atasözlerinin ele alınışında Kazakları ve Kazak kültürünün genel özelliklerini, inanış ve beklentilerini açıkça görebilmekteyiz. Kazaklar, Türk kültürü içerisinde benliklerini muhafaza etme, gelenek ve göreneklerini bağlı kalma noktasında sağlam bir bilince sahiptirler. Ayrıca vatan, millet, devlet, din gibi konularda genel olarak bir olumlu bakış bulunmaktadır. İnsan ilişkileri, zenginlik gibi farklı konularda yer yer olumsuz bakış açılarının da varlığı görülmektedir.

İkinci Bölüm (s. 289-997) Konularına Göre Kazak Atasözleri adını taşımaktadır. Bu bölüm de kendi içinde on beş bölüme ayrılmaktadır. Bunlar; İsan Ilişsileri ile IIlgili; Vatan, Millet, Halk ve Yönetim ile Illgili; Toplumsal Statü ile Ilgili; Kişilik Özellikleri ile Illgili; Yiyecek ve içecekler ile Illgili; Özel Günler ile IIlgili; İs, Çalışma ve Meslekler ile Ilgili; Tabiat ile Ilgili; Hayvanlar ve Avcılık ile İlgili; Insan Vücudu ile Illgili; Giysiler ve Eşyalar ile IIlgili; Eğitim, Bilim ve Sanat ile IIIgili; Hayat, Ölüm ve Sağlık ile Illgili; Din ve İnanışlar ile Ilgili; Diğer Konular ile Ilgili Atasözleri şeklinde sınıflandırılmıştır. Bu bölümde konuları bakımından Kazak atasözlerini ele alan araştırmacı ilk önce Kazak Türkçesinde bulunan atasözünü vermiş ardından o atasözünü Türkiye Türkçesine aktarmıştır. Daha sonra ise Kazak Türkçesindeki atasözünün benzeri Türkiye Türkçesinde varsa onu da ekleyerek karşılaştırmalı bir çalışma yapmıştır. Burada şu örnekleri verebiliriz:

- Kötere almasan qosa arqala: Kaldıramazsanız birlikte sırtlayın. Bir elin nesi var iki elin sesi var.

- Özine qaray qosağı, qonsağına qaray oşağı: Kendisine göre eşi, eşine göre ailesi. Tencere yuvarlanmış, kapağını bulmuş.

- Qızıqqanğa qıysıq ayaq ta suluw körinedi: Illgilenen kişiye çarpık pacaklı bile güzel görünür. Gönül kimi severse güzel odur.

Kazak Atasözleri kitabının son bölümü ise Sözlük (s. 999-1169)'tür. Burada sözlük malzemesi Kazak Türkçesindeki atasözlerinin içerdiği söz varlığından oluşmaktadır. Sözlükte madde başı olarak alınan her kelimenin anlamı açıklanmış daha sonra o kelimenin geçtiği atasözünden örnek verilmiştir.

Eserin sonunda ise yararlanılan kaynaklar bulunmaktadır. Burada yazar eserini ortaya koyarken birçok yerli ve yabancı kaynaktan faydalanmış ve bunları eserin "Kaynaklar" kısmında sıralamıştır.

Doç. Dr. Uğur GÜRSU tarafından yayımlanan Kazak Atasözleri isimli çalışma gerek sistematiği gerekse konulara bakış açısı bakımından atasözleri ile ilgili önemli bir çalışmadır. Türkiye Türkçesindeki ve Kazak Türkçesindeki atasözlerinin karşılaştırılmalı olarak ele alındığı eser bu alanlarla ilgili çalışanların sıklıkla başvuracağı bir kaynaktır. Doç. Dr. Uğur GÜRSU'yu bu kapsamlı çalışmasından dolayı tebrik ediyoruz. 
